It you do not need this publication after it has served your purpose, please return it to the Geological Survey, using the official mailing label at the end

UNITED STATES DEPARTMENT OF THE INTERIOR

GEOLOGY AND BIOLOGY OF NORTH ATLANTIC DEEP-SEA CORES

Part 9. SELENIUM CONTENT AND CHEMICAL ANALYSES

GEOLOGICAL SURVEY PROFESSIONAL PAPER 196-F 

UNITED STATES DEPARTMENT OF THE INTERIOR

Harold L. Ickes, Secretary

GEOLOGICAL SURVEY

W. C. Mendenhall, Director

Professional Paper 196-F

\section{GEOLOGY AND BIOLOGY OF \\ NORTH ATLANTIC DEEP-SEA CORES \\ BETWEEN NEWFOUNDLAND AND IRELAND}

Part 9. SELENIUM CONTENT AND CHEMICAL ANALYSES

BY

Glen Edgington and H. G. Byers

UNITED STATES

GOVERNMENT PRINTING OFFICE

WASHINGTON : 1942

For sale by the Superintendent of Documents, Washington, D. C. . . . . . - Price 15 cents 


\section{CONTENTS}

Outline of the complete report

Summary of the complete report

Summary of the complete report

General introduction, by W. H. Bradley

Significance of the investigation

Location of the core stations.

Personnel and composition of the report

Methods of sampling and examination

content and chemical analyses, by Glen Edgington and H. G. Byers

Analytical procedure

Analytical results

Discussion of analyses.-

Selenium_

Index

\section{ILLUSTRATIONS}

Plate 1. Bathymetric chart of a part of the North Atlantic Ocean showing the location of the core stations.

2. Longitudinal sections of the air-dried cores.

1. Profle across the numbered core stations............................

\section{TABLES}

TABLE 1. Geographic location, length of cores, and depth of the water from which they were taken.

34. Chlorine content of dry sample and chlorine lost by ignition

35. Chemical analyses of sea-bottom cores

36. Silica-sesquioxide and silica-alumina ratios of sediments 


\section{OUTLINE OF THE COMPLETE REPORT}

Foreword, by C. S. Piggot.

General introduction, by W. H. Bradley.

PART 1. Lithology and geologic interpretations, by M. N. Bramlette and W. H. Bradley.

2. Foraminifera, by Joseph A. Cushman and Lloyd G. Henbest.

3. Diatomaceae, by Kenneth E. Lohman.

4. Ostracoda, by Willis L. Tressler.

5. Mollusca, by Harald A. Rehder.

6. Echinodermata, by Austin H. Clark.

7. Miscellaneous fossils and significance of faunal distribution, by Lloyd G. Henbest.

8. Organic matter content, by Parker D. Trask, H. Whitman Patnode, Jesse LeRoy Stimson, and John R. Gay.

9. Selenium content and chemical analyses, by Glen Edgington and $H$. G. Byers. 


\section{SUMMARY OF THE REPORT}

In May and June 1936 Dr. C. S. Piggot of the Geophysical Laboratory, Carnegie Institution of Washington, took a series of 11 deep-sea cores in the North Atlantic Ocean between the Newfoundland banks and the banks off the Irish coast. These cores were taken from the Western Union Telegraph Co.'s cable ship Lord Keluin with the explosive type of sounding device which Dr. Piggot designed. In the fall of that year he invited a group of geologists of the l'nited States Geological Survey to study the cores and prepare a report. Biologists of the United States National Museum, the University of Buffalo, and chemists of the United States Department of Agriculture cooperated in the investigation and contributed to the report.

The westernmost core of the series (No. 3) was taken in the blue mud zone, but all the others were taken in parts of the ocean where the bottom is blanketed with globigerina ooze. The shortest cores are No. 8 , taken on the mid-Atlantic ridge in 1,280 meters of water, and No. 11, taken where the core bit struck volcanic rock. The cores range in length from 0.34 to 2.93 meters and average 2.35 meters. They were taken at depths ranging from 1,280 to 4,820 meters.

Lithology and geologic interpretations.-In about 20 representative samples from each core the percentages of calcium carbonate, clay and silt, and. sand were determined and plotted, and the relative abundance of Foraminifera, coccoliths, and diatoms was estimated. Material between these guide samples was examined microscopically, especially in certain critical zones.

Two zones were noted in which silicic volcanic ash (refractive index near 1.51) is common. The upper ash zone was found in all the cores except No. 11, but the lower one was found only in the lower part of cores 4 to 7 . In core 3 the upper ash zone is represented by shards scattered very sparsely all through the core, as this core, despite its length of 2.82 meters, apparently did not reach the bottom of the ash zone. The upper ash zone, together with other adjacent lithologic zones, serves to correlate the cores, and the lower ash zone, found west of the mid-Atlantic ridge, helps to confirm the correlation.

Besides the zones of volcanic ash four other zones distinctive in lithologic character were found. These zones are characterized by a relative abundance of sand and pebbles, by a smaller percentage of calcium carbonate, and by a sparsity of Foraminifera and coccoliths. They are distinctive also in texture. The pebbles are subrounded to angular and include a wide variety of rock types-sandstone, gneiss, soft shale, and limestone-of which limestone is the most common. Some of the pebbles are as much as 2 centimeters across. These zones are interpreted as glacial marine deposits formed during the Pleistocene glacial epoch, when continental glaciers were eroding the land. Drift ice from the continental glaciers apparently transported considerable quantities of rock debris far out into the ocean basin.

Between the glacial marine zones found in the North Atlantic cores the sediments consist chiefly of foraminiferal ooze or marl, much like that which is forming today in the same area.

The uppermost glacial marine zone is represented in all the cores except Nos. 3 and 11 and lies just below the upper volcanic ash zone. In cores 4 to 7 the glacial zones are relatively thin and are spaced at approximately equal intervals; between the third and fourth glacial zones (in descending order) is the lower volcanic ash. East of the mid-Atlantic ridge only the uppermost glacial zone has been identified. Other glacial marine deposits are recognizable but their correlation is less certain.

Three interpretations are offered as possible explanations of the four glacial marine zones. The first is that each glacial marine zone represents a distinct glacial stage of the Pleistocene and that each zone of foraminiferal marl separating two glacial marine zones represents an interglacial stage. This interpretation seems least probable of the three. The second interpretation is that the upper two glacial marine zones and the intervening sediment may correspond to the bipartite Wisconsin stage, whereas the lower two represent distinct glacial stages of the Pleistocene separated from each other and from the zone representing the Wisconsin stage by sediments that represent interglacial epochs no greater in length than postglacial time. This interpretation seems to imply too short a time for most of the Pleistocene epoch. The third interpretation, which is favored by the authors, is that each of the four glacial marine zones represents only a substage of the Wisconsin stage. This implies that the North Atlantic at approximately $50^{\circ}$ north latitude for comparatively long periods of time alternately contained an abundance of drift ice and then was quite, or nearly free of ice, while on land a continental ice sheet persisted, though it alternately waned and grew:

In the four cores in which the postglacial sediments are thickest the pelagic Foraminifera, according to Cushman and Henbest, reveal an interesting condition. These organisms indicate that during the middle part of the postglacial interval the temperature of the surface water in that part of the North Atlantic was somewhat higher than prevails today.

On the assumptions that the top of the uppermost glacial marine zone represents the beginning of the postglacial epoch as defined by Antevs, and that this was probably as much as 9,000 years ago, the postglacial sediment in these cores accumulated at a rate of about 1 centimeter in 265 years; but, because the sea probably cleared of detritus-laden drift ice long before the land in the same latitude was cleared of the retreating continental ice sheet, the average rate of accumulation may have been as low as 1 centimeter in 500 years.

Coarse-grained sediment on the tops of ridges and fine-grained sediment in the deeper basins indicate that currents move across these ridges with sufficient velocity to winnow out the finer particles and sweep them into deeper basins beyond.

The fact that the glass shards in the volcanic ash zones have been reworked and distributed without any gradation in size through many centimeters of the overlying sediments leads us to believe that mud-feeding animals are continually working over these shards and other particles of sand and silt so that they are redistributed at successively higher levels. The shards and other particles may also be reworked by gentle bottom currents that move the material from mounds and ridges on the sea floor and drift it about over the adjacent flatter areas.

Several layers in the cores are sharply set off by the coarser grain size of the sediment or by a regular gradation in grain size from coarsest at the base to fine at the top. These may be a result of submarine slumping.

The term globigerina ooze is used loosely in this report to designate sediment, half or more than half of which, by weight, consists of Foraminifera. This usage accords more closely with 
the usage adopted by Correns in the Meteor reports than with the usage of Murray and Chumley in the Challenger reports, which was based solely on the carbonate content. Limy muds containing a lesser but still conspicuous number of Foraminifera are referred to as foraminiferal marl. The carbonate content of the globigerina ooze in these cores ranges from 46.6 to 90.3 percent and averages 68.2 percent. In 191 samples representing all the lithologic types, the carbonate content ranges from 10.0 to 90.3 percent and averages 41.3 percent. Coccoliths are abundant in many parts of the cores, but by reason of their small size they rarely make up as much as 10 percent of the sediment Pteropods are rather numerous in parts of the cores taken on the mid-Atlantic ridge and on the continental slope off the Irish coast.

Most of the calcium carbonate in these sediments consists of the tests and comminuted fragments of calcareous organisms. The finest particles of carbonate are of indeterminate origin, but their irregular shape and range in size suggest that they are largely the finest debris of the comminuted organisms rather than a chemical precipitate. Clusters or rosettes of calcium carbonate crystals were found in many samples, but they are not abundant. They evidently formed in the mud on the sea floor.

No conclusive evidence of an increase in magnesium carbonate with depth was found, though some of the data suggest it. The magnesium carbonate is somewhat more abundant in the glacial marine zones than elsewhere, but its concentration in those zones is probably accounted for by the presence of clastic grains and pebbles of dolomite.

Diatom frustules, radiolarian skeletons, and sponge spicules are the most common siliceous organic remains found in the cores, and these generally form less than 1 percent of the sediment. One notable exception is the sediment in the middle part of core 9 , just east of the mid-Atlantic ridge, which contains 50 percent or more of diatoms.

Ellipsoidal and elongate or cylindrical pellets that appear to be fecal pellets are plentiful in the mud at the tops of cores 10 and 12, taken in the eastern part of the North Atlantic, but were not found elsewhere. No attempt was made to identify them further.

The sand-size material showed no marked variation in the mineral composition of the clastic grains at different horizons within individual cores 'and no conspicuous lateral variation from core to core. The mineral grains in the sand-size portions were not separated into light and heavy fractions, but simple inspection showed that grains of the heavy minerals are somewhat more common in the glacial marine deposits than elsewhere. Well-rounded sand grains are sparsely scattered through all the cores, but they are rather more plentiful in the' glacial marine zones. These grains, which range in diameter from about 0.1 to 1.0 millimeter and average 0.5 millimeter, have more or less frosted surfaces. They may have been derived from the reworking of glacial marine deposits or they may have been rafted by seaweeds. Little was done with the clay minerals other than to note that most of them have the optical properties of the beidellite or hydrous mica groups.

Six samples were tested with a 10-inch spectograph, which revealed the presence of appreciable amounts of barium and somewhat less of boron in each sample. All the samples gave negative tests for antimony, beryllium, bismuth, cadmium, germanium, lead, silver, tin, and zinc.

The original porosity of several samples in core 3 was calculated from the porosity of the dried samples. The original porosity plotted against depth in the core seems to indicate that fine-grained blue muds buried to a depth of 2 or 3 meters in the ocean floor are appreciably compacted.

Partial mechanical analyses of nearly 200 samples were made and plotted, but only four complete mẹchanical analyses were made. The complete analyses were made by the sedimentation method and include four distinctive types of sediment.

Pumiceous fragments and smaller shards of basaltic volcanic glass (index of refraction near 1.60) are scattered throughout all the cores, but are somewhat more common east of the mid-Atlantic ridge than west of it. Unlike the alkalic volcanic ash it shows no conspicuous concentration in zones. Most of the basaltic glass and pumice has a thin surface alteration film of palagonite. The films are thickest on fragments in cores taken from ridges where oxygen-bearing waters had free access to the sediments. Two varieties of palagonite are recognized.

Core 11 represents only 34 centimeters of the sea floor because the core bit encountered deeply altered olivine basalt. About 15 centimeters of globigerina ooze rests on and within irregular cavities of the upper surface of a mass of clay that is apparently altered basalt. This clay is impregnated with manganese and contains nodular lumps of altered basalt. Part of the basalt near the base of the core is less altered. The clay contains scattered grains of sand and foraminiferal shells in which the original calcium carbonate has been replaced by a zeolite resembling phillipsite. This core may have penetrated the upper, deeply altered part of a submarine lava flow, but the evidence is not conclusive.

Core 10 contains two rather thick beds of distinctive clayey mud. About half of this mud is a beidellite or hydrous mica type of clay and the other half is made up of silt-size particles of basaltic glass, magnetite, augite, and calcic plagioclase. It contains very little common clastic material and exceedingly few Foraminifera. The composition and texture suggest that this mud was derived largely from a submarine volcanic eruption that threw into suspension clay particles perhaps partly from the normal sediment and from deeply altered basalt. A complete chemical analysis of this mud is given.

Foraminifera.-From these, cores 184 samples representing every lithologic zone were examined for calcareous fossils. All but five samples contained Foraminifera. As in existing oceans deeper than several hundred meters, pelagic Foraminifera greatly outnumber the bottom-dwelling forms, though in variety of form and in number of genera and species the bottom forms greatly exceed the pelagic. Several zones of relatively pure globigerina ooze were found, and many in which the ooze was clayey or sandy. Though variations in temperature were reflected by faunal changes, the general bathymetric facies of the faunas appear to be rather uniform throughout each core. The bottom faunas are least varied and prolific in cores from the deepest water, whereas in cores from the shallowest water they are by far the most varied and prolific. Cores from intermediate depths contain faunas of intermediate bathymetric facies. These relations to depth are, in general, characteristic also of faunas in the existing oceans. A few scattered specimens of Elphidium or Elphidiella were found. These genera thrive in shallow water, but in these cores the shells are so rare, so erratically distributed, and in some so poorly preserved that it seems probable they were rafted in by seaweeds or ice and therefore have no significance as indicators of depth. No species peculiar to the Miocene or Pliocene were found. It appears, therefore, that all the sediments penetrated by the cores are younger than Pliocene. Alternation of faunas that are characteristic of the warm and cold climates of the present day indicates great climatic changes during the time represented by these cores. The foraminiferal facies characteristic of cold and warm climates correlate with the alternating sequence of glacial-marine and warmer-water sediments indicated by the lithology. This correlation suggests that all the sediments in these cores are of Recent and Late Pleistocene age.

Diatomaceae.-Fifty-two species and varieties of diatoms were found in these cores. A large percentage of the species are neritic, warm-water forms that are foreign to the region today. Several 
alternations of warm-water and cold-water diatom floras occur in most of the cores, but their position in the cores is not in accord with the alternations of - temperature inferred from lithology and foraminiferal facies. It is suggested that this disagreement may be due to the much longer settling time of the diatoms and that allowance should be made for it. The time equivalent of this difference of phase, as calculated from the vertical displacement necessary for the best approximation to agreement between the foraminiferal and lithologic data on the one hand and the diatom data on the other is of the order of 23,000 years. This figure appears absurdly high and a figure of several hundred years, based on extrapolation of experimentally timed settling in a relatively small vessel, is considered more reasonable. The action of cold and warm currents, some surficial and some deep seated, is suggested as the possible cause of the apparently erratic distribution of the diatoms. The possibility that the phase difference of 23,000 years mentioned above is related to shifts of ocean currents caused by advances and recessions of drift ice is offered as a speculation. Of 52 species and varieties illustrated, 2 species and 1 variety are described as new.

Ostracoda.-In preparing a series of samples from the cores for the study of the Foraminifera about 175 specimens of Ostracoda were found. These belong to 13 genera and 27 species, all living forms, though 12 of the species are known also as fossils. Most of the ostracodes were found in three cores that were taken in the shallowest water (1,280 to 3,230 meters). One of these cores (No. 8) was from the top of the mid-Atlantic ridge and the other two (Nos. 12 and 13) were from the continental slope southwest of Ireland. In the cores from deeper water $(3,250$ to 4,820 meters) ostracodes were scattered very sparsely. Like most marine ostracodes, all the species found in the cores are bottom dwellers. Most of the species are decidedly' cold-water forms that are found in tropioal waters only at great depth, where the temperature is near freezing.' Northern forms predominate; only 2 of the species have not previously been known from northern waters, and 10 species are definitely Arctic forms. A few species that have a wider temperature range live not only in cold waters but also in the deep warm water of the Mediterranean.

The predominance of distinctly cold-water ostracodes and the prevalence of Arctic forms suggest that the temperature of the water in this part of the North Atlantic was formerly somewhat lower. But, as might be expected from the fact that all the species in these cores are bottom dwellers, their distribution in the cores shows no evident relationship to the cold and warm zones indicated by the composition and texture of the sediments and by the pelagic Foraminifera.

Mollusca.- - The mollusks recovered from these cores can be divided into two groups, the pteropods and the other gastropods and pelecypods. The pteropods are by far the more numerous. All the specimens of the pelecypods and gastropods, other than pteropods, are representatives of deep-water species that are now living in the same boreal or cold-temperate waters. Also, the fragments that could not be identified specifically belong to forms that have congeners now living in these waters. The fauna of these cores, even that taken from the lower parts of the cores, shows no appreciable difference from that now living in the same localities. Among these mollusks no evidence of shallower or considerably deeper water is demonstrable. Molluscan remains, other than those of pteropods, are too scarce to attempt to differentiate cold- and warm-water facies, as was done with the foraminiferal faunas.

The Pteropoda, which are far more abundant in the cores than the other mollusks, belong to two genera and three species. One of the species is new. The geographic distribution of the pteropods is limited more by the temperature of the surface water than by any other factor. Nevertheless, as one species is cosmopolitan, one boreal, and one a new species thought to be the northern analogue of a more southern species and as all three species occur together, they have no significance for differentiating cold- and warm-water facies. These organisms are pelagic and their shells have a rather wide distribution, but, as they are found on the sea floor at depths ranging from 247 to 3,750 meters, they are of little aid as indicators of depth of the ocean at the time these deposits were laid down.

Echinodermata. - The remains of 9 species of Echinodermata were found in the cores. These include 1 ophiuroid, 7 echinoids, and 1 crinoid. No remains of asteroids were found. All the echinoderms found belong to species now living in that part, or adjacent parts, of the North Atlantic. Echinoderm remains are rather uniformly distributed among the cores, but they are most numerous in core 8 , which was taken in 1,280 meters of water on the crest of the mid-Atlantic ridge. By far the commonest species is Pourtalesia miranda, remains of which were found in nearly two-thirds of the 82 echinoderm-bearing samples and in all the cores except 8 and 11 .

Because the association of species in the cores is closely similar to the association of living species in that part of the North Atlantic and because the association of species within each core is independent of the distance below the top of the core it appears that neither the distribution nor the composition of the echinoderm fauna has changed significantly during the interval represented by these cores. No evident relationship was found between the distribution of the various species of echinoderms and the cold- and warm-water facies of the sediments indicated by both the Foraminifera and the lithology.

Miscellaneous fossils and significance of faunal distribution.The principal fossil groups represented in the cores, listed in order of abundance, are foraminifers, diatoms, echinoids, siliceous sponges, radiolarians, ophiuroids (spines and plates) ostracodes, and pteropods. Remains of barnacles, brachiopods, pelecypods, holothuroids, bryozoans, gastropods, and teleost fishes (otoliths) were also found, but all these are rare. The foraminifers, diatoms, ostracodes, echinoderms, pelecypods, and gastropods were studied separately by specialists. The other groups are briefly noted and illustrated for the sake of the record. The most varied and prolific faunas were found in the three cores that were taken from the shallowest water and the least varied and least prolific were found in those from the deepest water. The bottom-living faunas throughout each core have a broadly similar bathymetric facies, and the bathymetric facies of each core appears to correspond to that of the fauna now inhabiting that locality. Faunas having the characteristics of very shallowwater marine faunas are either absent or, if present, are so rare and efratically distributed that they appear to be foreign in origin rather than indigenous. Ostracodes and pteropods are locally abundant in the cores from the shallower water, but are absent or rare at all horizons in those from the deeper water. The distribution and bathymetric facies of the faunas weigh heavily against the hypothesis of extreme changes in ocean level during the later part of the Pleistocene.

Organic matter content.-The content of organjic matter, as determined from 123 samples, ranges from 0.1 to 1.0 percent of the total weight of the sediments, and the average is about 0.5 percent. As in near-shore sediments, it is influenced by the configuration of the sea bottom. It is small on ridges and large in the deeps. It is particularly large in the sediments at the base of the east slopes of ridges, owing in part probably, to material washed from the vicinity of the ridges by eastwardsweeping ocean currents. The organic matter content of the upper layers of the sediments in the abyssal deeps is greater for a few hundred miles east of the mid-Atlantic ridge than it is for a similar distance west of the ridge. The organic content does not vary consistently with depth exeept in core three, taken at the foot of the continental slope east of the Grand 
Banks, where it seems to decrease about 25 percent in the first 1.5 meters. The organic matter content of the sediments tends to be greater in the warm zones, than in the cold zones, and in general it is slightly greater in sediments which, according to Cushman's determination of the Foraminifera, were probably deposited in areas in which the surface water was relatively warm. The organic content is rather closely related to the texture, and increases with increasing fineness of the sediments. The rate of deposition of organic matter is greater east of the mid-Atlantic ridge than west of it, presumably owing in part to a greater supply of plankton and in part to a slower rate of decomposition of the organic matter after it is laid down in the sediments. The slower rate of decomposition within the sediments is inferred from the greater state of reduction of the sediments, which is indicated by the nitrogen-reduction ratio. The nitrogen-reduction ratio suggests a slight increase in state of reduction with increasing depth of burial in the upper part of the deposits, but indicates no significant change in the lower part. The percentage of organic content tends to increase as the percentage of Foraminifera in the sediments decreases, but it shows no relationship to the calcium-carbonate content.

Selenium content and chemical analyses.-As a part of a comprehensive investigation of the distribution of selenium in marine sediments and soils derived from them complete fusion analyses were made of 20 samples from the suite of 11 cores. These samples were taken from the tops of the cores and at intervals of approximately 1 and 2 meters below the top. In addition, 1 core taken on the continental shelf off Ocean City, Md., and 3 cores from the Bartlett Deep were sampled and analyzed, making a total of 31 analyses. The results of the analyses include all the normal analytical data obtained in a so-called complete soil analysis by the fusion method, and, in addition, determinations of organic matter, nitrogen, chlorine (in all but 12 analyses), hygroscopic water, and selenium. All the samples were analyzed with the entrained sea salts. The core from the continental shelf off Ocean City contained the most selenium-at the top 0.6 part per million, at 1 meter 1.0 , and at 2 meters 2.0 parts per million. The samples from the North Atlantic cores showed a selenium content ranging from 0.06 to 0.8 part per million. Of the samples from the Bartlett Deep one contained 0.2 part per willion of selenium, but all the others contained less than 0.08 part per million. No evidence was found of a relation between the selenium content and volcanic activity.

The silica-sesquioxide and silica-alumina ratios are tabulated and their significance as means of comparing the analyses is discussed. 


\title{
FOREWORD
}

\author{
By C. S. Piggot ${ }^{1}$
}

During the last cruise (1927-29) of the nonmagnetic ship Carnegie of the Department of Terrestrial Magnetism of the Carnegie Institution of Washington a number of samples of the deep ocean bottom were obtained by means of the telegraph snapper. The Geophysical Laboratory determined the radium content of these samples and found that they contained a concentration of radium ${ }^{2}$ as astonishingly high as that reported by Jol ${ }^{3}$ and Pettersson ${ }^{4}$ from similar samples taken by the Challenger and Princess Alice II. This high radium concentration in the surface layer of the ocean bottom, which constitutes 72 percent of the surface of the globe, raises questions of great significance to both oceanography and geophysics. An obvious question is whether radium in so high a concentration is present down through all deep-sea sediments or only at the surface. ${ }^{5}$ If the first hypothesis is correct it indicates the presence of uranium throughout the sediments, whereas the second indicates the existence of radium itself, presumably separated out from the sea water. The study of this question requires samples of a type analogous to the cores so extensively used in subsurface exploration on land. Inquiries among oceanographic organizations established the fact that although some cores a meter or more in length had been obtained from relatively shallow water, many of them were much distorted by the time they reached the laboratory, and none as long as 1 meter had been obtained from a depth of 4,000 meters or more. ${ }^{6}$ Those engaged in such research emphasized the need of apparatus capable of obtaining undistorted cores from great depths. In 1933 the Council of the Geological Society of America approved a grant for the development of such apparatus.7 Fortunately, cooperation was obtained from several special

\footnotetext{
1 Geophysical Laboratory, Carnegic Institution of Washington.

'Piggot, O. S., Radium content of ocean-bottom sediments: Am. Jour. Sci., 5th ser., vol. 25, pp. 229-233, 1933.

$3 \mathrm{Joly}, \mathrm{J}$., On the radium content of deep-sea sediments: Philos. Mag., vol. 16, pp. 180-197, 1908.

- Pettersson, Hans, Teneur en radiam des dépots de mer profonde: Resultats de Campagnes Scientifiques par Albert I er Prince Souverain de Monaco, vol. 81, 1930.

- Piggot, C. S., op. cit., p. 233.

- Since these inquirles were made $\mathrm{D}$. Wolansky has published her review in the Geologische Rundschau (Band 24, Heft 6, p. 399, 1933), in which sbe refers to the work of A. D. Archanguelsky in the Black Sea (Soc. Naturalistes Moscow Bull., new ser. vol. 35, pp. 264-281, 1927). Wolansky mentions cores 3 to 4 meters long from depths of 2,237 meters. See also Wiss. Ergeb. Deutschen Atlantischen Exped. Meteor, 1925-27, Band 3, Teil 2, Lief. 1, pp. 4-28, 1935.

7 Piggot, C. S., Apparatus to secure core samples from the ocean bottom: Geol 8oc. America Bull., val. 47, pp. 675-684, 1936.
}

agencies, particularly the Burnside Laboratory of the E. I. du Pont de Nemours, whose ballistics expert, Dr. B. H. Mackey, offered fundamental suggestions and made many essential calculations and tests; also the United States Bureau of Lighthouses, from whose lightship tender, the $S$. S. Orchid, many experimental soundings were made. Several forms of the apparatus were developed and tested, and in August 193614 satisfactory cores were obtained from the canyons in the continental shelf off New Jersey, Delaware, and Maryland, and another from the ocean floor below 2,500 meters of water. ${ }^{8}$ This first deep-sea test was made possible by the cooperation of the Woods Hole Oceanographic Institution and was carried out in connection with an investigation of the submarine canyons by $\mathrm{H}$. C. Stetson of that institution. This test demonstrated the feasibility of the apparatus as built but suggested some minor changes in design. These were incorporated in another apparatus, which was put aboard the cable ship Lord Kelvin at Halifax, Nova Scotia. Through the courtesy of Mr. Newman Carlton, Chairman of the Board of Directors of the Western Union Telegraph Co., the Carnegie Institution of Washington was invited to have a member of its staff accompany the Lord Kelvin while that ship was engaged in making repairs to the North Atlantic cables, in order to test the apparatus in deep water. This offer was gladly accepted, and in May and June of 1936 I was on board the Lord Kelvin with the apparatus.

Because of the personal interest and cooperation of the commanding officer, Lt. Comdr. Bredin Delap, Royal Navy, retired, the undertaking was more successful than had been anticipated, and a suite of 11 excellent cores was obtained, extending from the Grand Banks of Newfoundland to the continental shelf southwest of Ireland.

All but two of these cores (Nos. 8 and 11) are more than 2.43 meters ( 8 feet) long, and all contain ample material for study. Of the two short cores, No. 8 was taken from the top of the Faraday Hills, as that part of the mid-Atlantic ridge is known, where the material is closely packed and more sandy and consequently more resistant; No. 11 came from a locality where the

- Cushman, J. A., Henbest, L. G., and Lohman, K. E., Nंotes on a core sample from the Atlantic Ocean bottom southeast of Now York City: Geol. Soc. America Bull, vol. 48, pp. 1297-1306, 1937. 
apparatus apparently landed on volcanic rock that may be part of a submarine lava flow. Soundings at the localities where the cores were taken show depths ranging from 1,280 meters at the top of the Faraday Hills to $\overline{4}, 820$ meters in the deep water between the mid-Atlantic ridge and the continental shelf.

The thorough test made possible by the interested cooperation of everyone on board the Lord Kelvin fully demonstrated the capacity of the apparatus and produced material from strata of oceanic sediments deeper than have ever before been available.
In order that this pioneer material might be examined to the best advantage and an adequate estimate made of the potentialities of cores of this type, a group of investigators representing various fields of science was invited to examine them. Efforts have been made to arrange the sequence of these investigations in such a way that the maximum information may be obtained with the minimum destruction of the samples.

The cores are now at the Geophysical Laboratory of the Carnegie Institution of Washington, where they and others that may be obtained by this laboratory will be held available'for further research. 


\title{
GENERAL INTRODUCTION
}

\author{
By W. H. Bradley
}

\section{SIGNIFICANCE OF THE INVESTIGATION}

The long cores of deep-sea sediment considered in this report represent a longer span of the earth's late geologic history, as recorded in abyssal sediments, than has been heretofore accessible. In a measure, therefore, this study has been exploratory. Because of that exploratory aspect we have not only presented the observations but also have deliberately speculated upon various possible interpretations of the features observed in the cores and upon their relations. with one another. Because the cores are few in number and widely spaced, we offer many of the interpretations not as definite conclusions but rather as suggestions to be tested by whatever coring may be done in the future in that part of the North Atlantic.

From this investigation it appears that glacial marine deposits may prove to be sensitive indicators of the climatic changes that caused the growth and decay of continental ice sheets during the Pleistocene. In particular, it seems that the glacial marine record may throw light on the climatic fluctuations that determined substages of the Pleistocene. The marine record was the result of a continuously operating series of causes such that the deposits of each glacial substage were separated from one another by the deposits of the intervening warmer substage. The record of each substage has remained intact and was not obliterated by readvances of the ice. As the equatorward extent of the glacial marine deposits implies a corresponding expansion of continental ice sheets, the extent of the deposits may be used as a measure of the intensity of the climatic changes, and their thickness may be used as a rough indicator of the duration of glacial substages. Similarly, the thickness and poleward extent of tongues of nonglacial sediment-the foraminiferal marl-are measures of deglaciation. The areal extent of these tongues of sediment can be determined by additional cores taken at properly located stations.

When the glacial marine record is more fully known it should provide a basis for correlating the Pleistocene history of Europe and North America.

Cores taken along the meridians in series extending from the Arctic regions into the tropical parts of the Atlantic should make it possible to map the southern limits of pack ice in the sea during successive glacial maxima, at least for the later part of the Pleistocene.
As the pelagic Foraminifera in these abyssal sediments are reliable indicators of surface-water temperatures in the Recent and Pleistocene epochs, it should be possible to trace southward into the tropics layers or beds of foraminiferal ooze that are the time equivalents of glacial marine zones. Such layers of foraminiferal ooze could then be correlated with the layer of globigerina ooze in the tropics that Schott ${ }^{9}$ identified as a relatively cold-water deposit that probably represents the last glacial epoch of the Pleistocene.

The study of climatology as well as geology may be advanced by the information to be derived from long sea-bottom cores. Significant evidence bearing on postglacial climatic changes may be obtained from minutely detailed study of the Foraminifera in cores taken in parts of the ocean where postglacial sedimentation has been comparatively rapid, as, for example, near the seaward edge of the blue-mud zone. On the assumption that such sediment accumulates at an essentially uniform rate, climatic fluctuations may be located approximately in time within the postglacial interval and may be correlated from place to place along the ocean margins from the Arctic to temperate or even tropical latitudes and perhaps also from continent to continent.

Archeology, also, might profit from the knowledge of a relatively timed and correlated sequence of climatic changes, for such changes may well have made a significant impress on the habits and migrations of peoples, particularly those that dwelt in regions where small changes in either temperature or rainfall were critical. As I have pointed out in an earlier paper, ${ }^{10}$ students of archeology and early history, particularly in the Mediterranean region, might profit much from detailed studies of long cores of the sediment in the deep basins of the Mediterranean. In cores from that sea, as elsewhere, changes in the foraminiferal faunas would indicate climatic changes, and the sediments would yield, in addition, evidence of volcanic eruptions and earthquakes. The time when the Sahara became a desert should also be recorded in the Mediterranean sediments by wind-blown sand. Such a change might conceivably be integrated with the wealth of archeo-

\footnotetext{
- Schott, W., Die Foraminiferen in dem äquatorialen Teil des Atlantischen Ozeans: Wiss. Ergeb. Deutschen Atlantischen Exped. Meteor, 1925-27, Band 3, Teil 3, Lief. 1, pp. 120-128,1935.

10 Bradley, W. H., Mediterranean sediments and Pleistocene sea levels: Science
} new ser., vol. 88 , pp. $376-379,1938$. 
logical records of the region, and the later volcanic eruptions and earthquakes might be correlated with early history.

Some of the problems sketched so briefly here are touched upon in the several chapters of this report, but most of them must be left for future investigators. Nevertheless, methods by which such problems may be attacked are described and discussed at considerable length, particularly in the chapters on "Lithology and geologic interpretations" and "Foraminifera."

\section{LOCATION OF THE CORE STATIONS}

The cores were taken along a slightly irregular line between the easternmost part of the Newfoundland Banks and the banks off the southwest coast of Ireland, as shown in plate 1. Each core obtained by the Piggot coring device is numbered to correspond with the station number of the cable ship Lord Kelıin. Stations 1 and 2 were trial stations at which preliminary tests were made to familiarize the crew with the apparatus, and no cores were preserved. The 11 cores studied are numbered consecutively, 3 to 13 . The relation between
M. N. Bramlette, J. A. Cushman, L. G. Henbest, K. E Lohman, and P. D. Trask. As the biologic phase of the work progressed it became evident that other organisms than the foraminifers and diatoms should be studied. Accordingly Mr. Henbest invited Dr. Willis I. Tressler, of the University of Buffalo, to examine the ostracodes, Dr. Austin H. Clark of the United States National Msueum, to examine the echinoderms, and Dr. Harald A. Rehder, also of the United States National Museum, to examine the mollusks.

The organic matter content of the sediments was studied by Mr. Trask in collaboration with Messrs. H. Whitman Patnode, Jesse LeRoy Stimson, and John R. Gay, all members of the American Petroleum Institute.

As part of a comprehensive research project on the distribution of selenium in marine sediments and the soils derived from them Dr. H. G. Byers and Mr. Glen Edgington, of the Bureau of Chemistry and Soils, United States Department of Agriculture, made complete chemical analyses of 20 samples from these deepsea cores. These analyses, together with analyses of

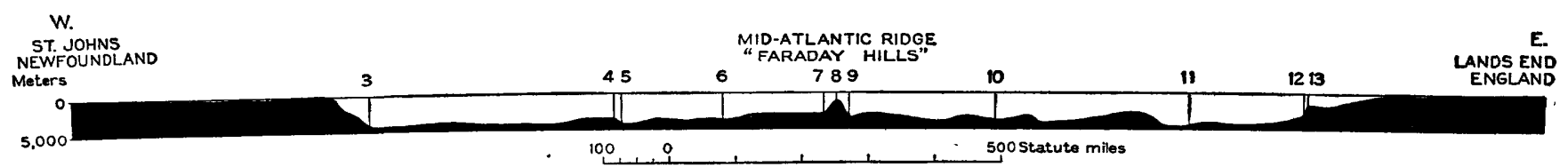

Figure 1.-Profle across the North Atlantic ncean along the line of the numbered core stations shown on plate 1.

the core stations and the submarine topography is shown in figure 1, which is a profile along the dashed line in plate 1 that connects the stations and extends from St. Johns, Newfoundland, to Lands End, England."

TABLE 1.-Geographic location, length of the cores, and depth of the water from which they were taken

\begin{tabular}{|c|c|c|c|c|}
\hline Core number & $\begin{array}{c}\text { Depth } \\
\text { of water } \\
\text { (meters) }\end{array}$ & $\begin{array}{l}\text { Length } \\
\text { of corre } \\
\text { (meters) }\end{array}$ & Lat. N. & Long. W. \\
\hline${ }^{2}$ & $\begin{array}{l}4,700 \\
3,955 \\
4,820 \\
4,125 \\
3,250 \\
1,280 \\
3,745 \\
4,190 \\
4,820 \\
3,230 \\
1,955\end{array}$ & $\begin{array}{l}2.81 \\
2.71 \\
2.82 \\
2.90 \\
2.62 \\
1.24 \\
2.76 \\
2.97 \\
.34 \\
2.43 \\
2.21\end{array}$ & $\begin{array}{l}46^{\circ} 03^{\prime} 00^{\prime \prime} \\
48^{\circ} 29^{\prime} 00^{\prime \prime} \\
48^{\circ} 8^{\prime} 00^{\prime \prime} \\
49^{\circ} 03^{\prime} 30^{\prime \prime} \\
49^{\circ} 22^{\prime} 00^{\prime \prime} \\
49^{\circ} 6^{\prime} 00^{\prime \prime} \\
49^{\circ} 40^{\prime} 00^{\prime \prime} \\
49^{\circ} 45^{\prime} 00^{\prime \prime} \\
48^{\circ} 3^{\prime} 08^{\prime \prime} 00^{\prime \prime} \\
49^{\circ} 37^{\prime} 00^{\prime \prime} \\
49^{\circ} 38^{\prime} 00^{\prime \prime}\end{array}$ & 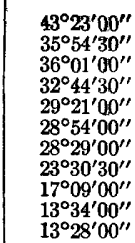 \\
\hline
\end{tabular}

PERSONNEL AND COMPOSITION OF THE REPORT

At the request of Dr. C. S. Piggot, of the Geophysical Laboratory of the Carnegie Institution of Washington, the following six members of the United States Geological Survey undertook a systematic study of the 11 deep-sea cores from the North Atlantic: W. H. Bradley,

"1 Data for plate 1 and flgure 1 were taken from International Hydrographic Bureau, Carte Générale Bathymétrigue des Oçans, 3d eri., sheets A-1 and B-1, coples of which ware furnished by the U. 8. Hydrographic Ofllce. samples from several other deep-sea cores and a discussion of the occurrence of selenium, are included in the chapter on "Selenium content and chemical analyses."

\section{METHODS OF SAMPLING AND EXAMINATION}

The Piggot coring device ${ }^{12}$ takes the cores in brass sampling tubes that have an inside diameter of $4.9 \mathrm{~cm}$. As soon as a core is taken, the tube is cut off at the approximate length of the core and sealed. The cores here discussed were opened under Dr. Piggot's direction at the Geophysical Laboratory of the Carnegie Institution of Washington. A longitudinal cut was made along one side of each brass core barrel by means of a milling cutter so adjusted that it did not cut quite through the wall of the tube. The thin strip remaining was then ripped out without letting brass chips get into the core. After allowing the mud cores to dry somewhat, but not enough to shrink away from the tube walls, the cores and core barrels were cut in half longitudinally with a metal-cutting band saw. In this cutting, the milled slot was held uppermost so that the saw cut only the lower wall of the core barrel and threw the cuttings downward, away from the core.

12 Piggot, O. S., Apparatus to secure core samples from the ocean bottom: Geol. Soc. Americs Bull, vol. 47, pp. 676-684, 1936. 
Each half core then remained undisturbed in its half cylinder cradle of brass core barrel. (See pl. 2.)

As several months elapsed between the time the cores were opened and the time this investigation began, the mud had dried thoroughly when Mr. K. E. Lohman took a succession of overlapping photographs of each core, about one fifth natural size. These photographs were then assembled as a key chart upon which were marked the parts from which samples for all phases of the investigation were taken. The dried segments' of mud shifted somewhat from their original places each time samples were removed, though care was taken to see that during sampling the segments kept their original order and orientation. By reference to this photographic key the findings of all the investigators have been correlated.

Mast of the material was hard enough to be sawed into blocks with a hack saw, but a few of the most friable parts were sampled with small channel-shaped scoops of sheet metal after the loose material on the surface had been brushed away.

Samples for all phases of this investigation were taken from only one half of each core, the other half being held intact in the Geophysical Laboratory. 



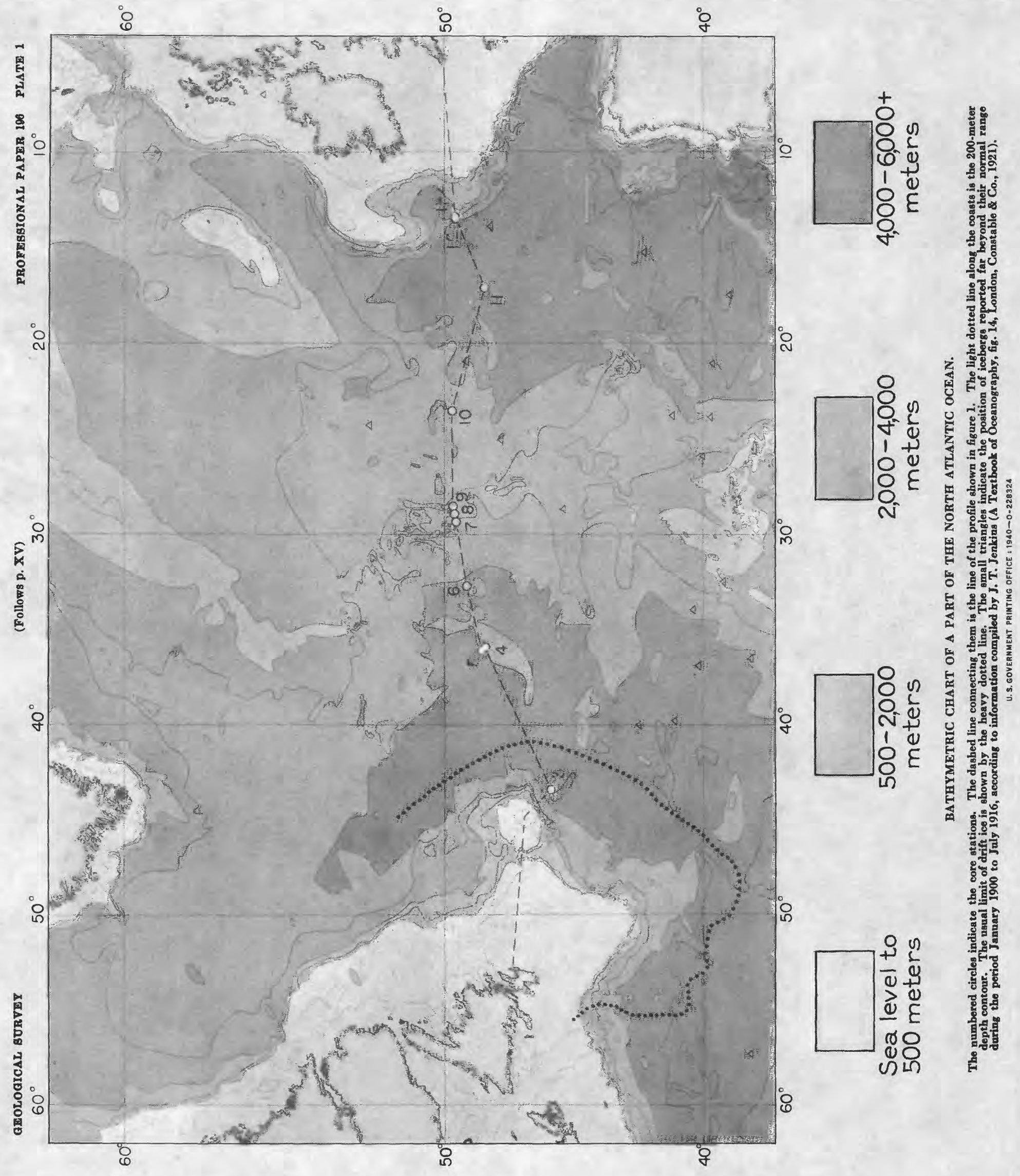



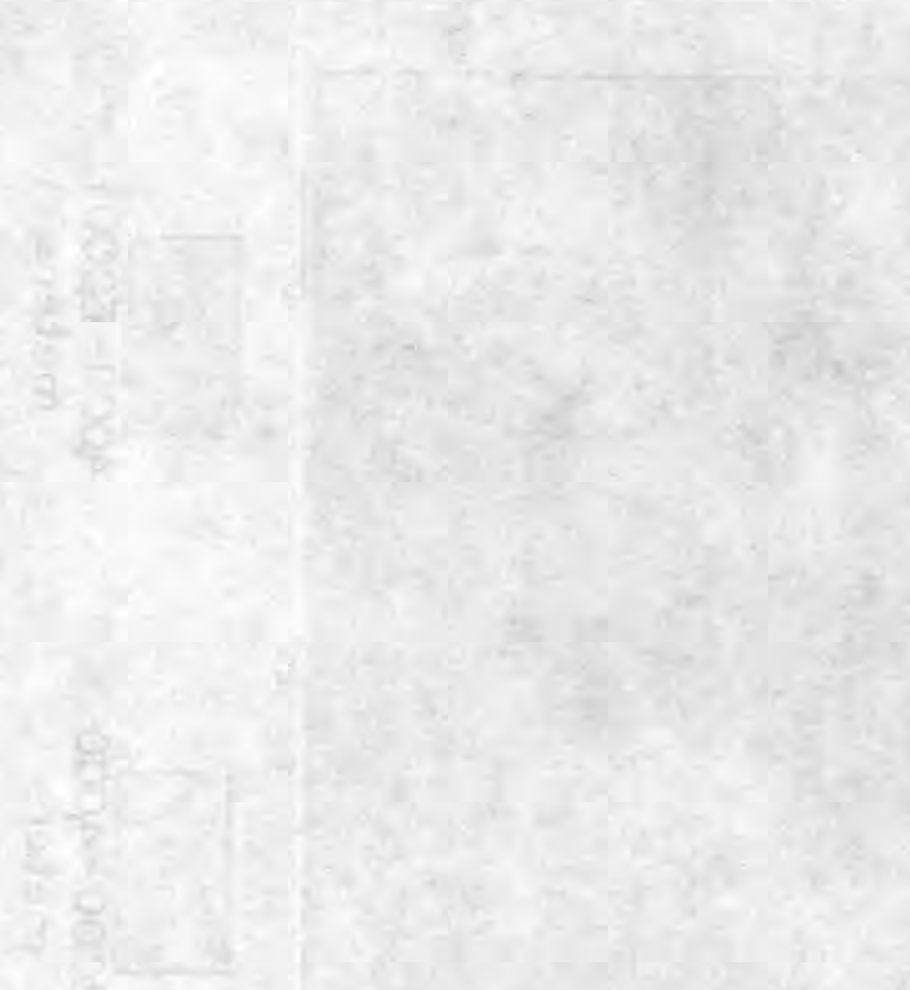


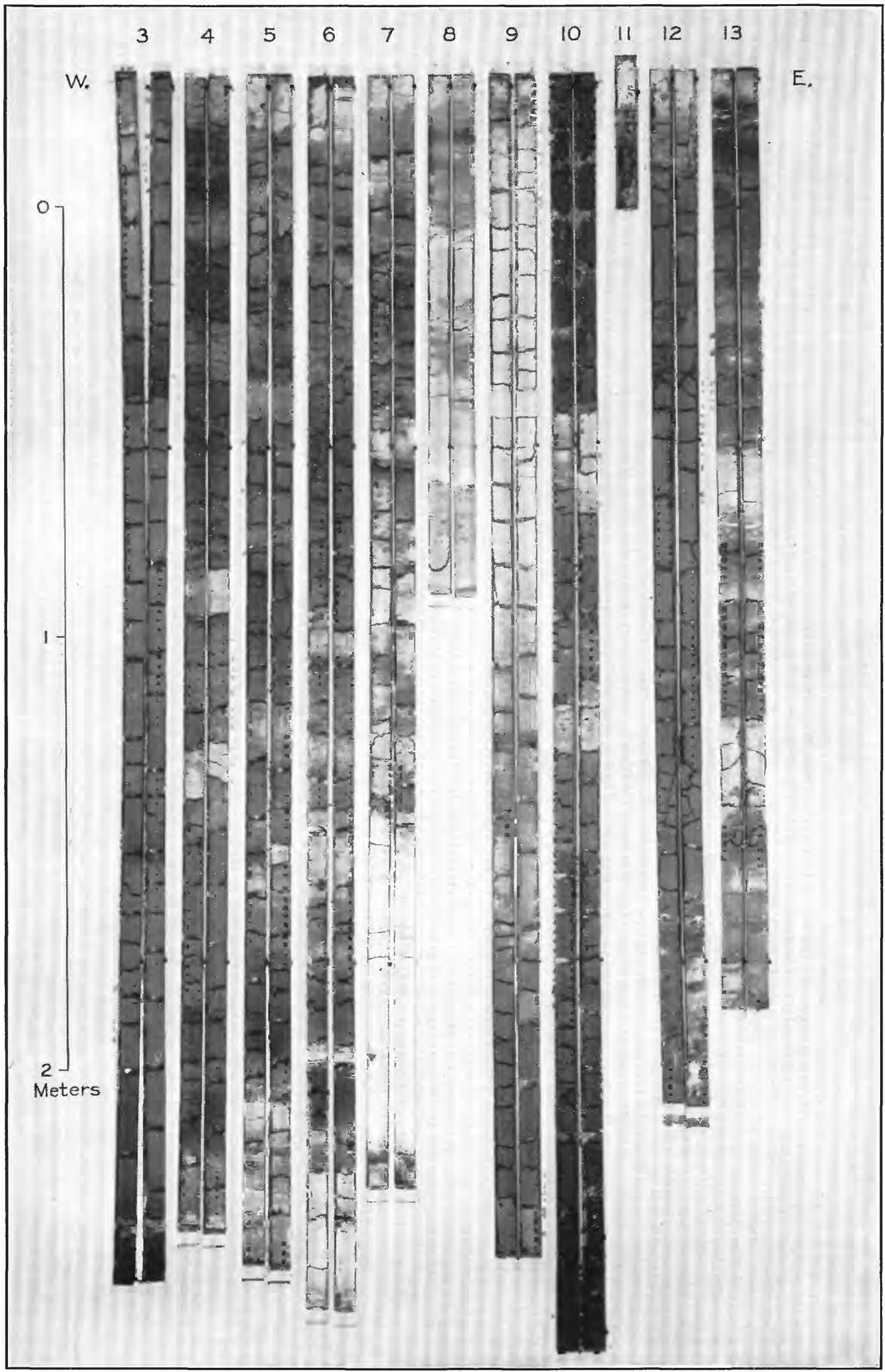

LONGITUDINAL SECTIONS OF THE AIR-DRIED CORES.

Half of the core harrel was removed from core 11, but the core itself was not cut. Photograph by Geophysical Laboratory, Carnegie Institution of Washington. 



\title{
GEOLOGY AND BIOLOGY OF NORTH ATLANTIC DEEP-SEA CORES BETWEEN NEWFOUNDLAND AND IRELAND
}

\author{
PART 9. SELENIUM CONTENT AND CHEMICAL ANALYSES
}

\author{
By Glen Edgington and H. G. Byers ${ }^{1}$
}

\section{INTRODUCTION}

For several years the Division of Soil Chemistry and Physics, formerly under the Bureau of Chemistry and Soils but now a part of the Bureau of Plant Industry, has been interested in analyses of profiles of soils and also in the origin and distribution of selenium in surface formations. For both these reasons the opportunity to examine chemically the sea-bottom cores, which were made available through the kindness of Dr. C. S. Piggot, was extremely welcome. These offer for the first time submarine profile samples for examination and comparison with samples of soil profiles, lacustrine deposits, and delta deposits. Though numerous samples of deep-sea deposits from various sources have been available, there is a singular absence of complete fusion analyses. These are virtually limited to analyses of a composite of 51 samples of red clay and of 52 samples of terrigenous clays by G. Steiger. ${ }^{2}$ These samples are partly collections from the Challenger expedition and partly from other expeditions. There are also analyses by Brazier and by Hornung ${ }^{3}$ of the acid-soluble and acid-insoluble portions of a considerable number of individual sediments; also 14 analyses by Caspari. ${ }^{4}$ These may be combined to give the composition of the sediment as a whole.

Many partial analyses of samples of ocean sediments are available from various sources, such as those by Fairchild on samples from Pago Pago Harbor ${ }^{5}$ and from the Gulf of Maine. ${ }^{6}$ In addition, Twenhofel ${ }^{7}$ has summarized numerous analyses of surface material, such as glacial, lacustrine, and delta deposits.

\footnotetext{
1 Glen Edgington, assistant chemist, and H. G. Byers, principal chemist, Division of Soil Chemistry and Physics, Bureau of Plant Industry.

Clarke, F. W., The data of geochemistry: U. S. Geol. Survey Bull. 770, p. 518, 1924.

${ }^{3}$ Murray, John, and Renard, A. F., Challenger Rept., Deep sea deposits, pp. 425$451,1891$.

4 Caspari, W. A., Composition and character of oceanic red clay: Royal Soc. Edinburgh Proc., vol. 30, pp. 183-201, 1910.

- Bramlette, M. N., Some marine bottom samples from Pago Pago harbor, Samoa: Papers Dept. Marine Biol., Carnegie Inst. Washington, vol, 23, pp. 9-23, 1926.

- Wells, R. C., Analyses of rocks and minerals: U. S. Geol. Survey Bull. 878, p. 67, 1936.

I Twenhofel, W. H., Treatise on sedimentation, 2d, ed., pp. 3-32, 247-276, Williams and Wilkins, 1932.
}

A great number of analyses of sedimentary deposits, which are now, or may become, parent material for soils, are also available. ${ }^{8}$

The analyses presented herewith include not only 20 samples selected by Dr. C. S. Piggot from the North Atlantic cores but also 3 samples from a core taken off Ocean Cily, Md., and 8. samples from 3 cores taken in the Bartlett Deep, in the Caribbean Sea. These additional samples offer some interesting relationships with those from the North Atlantic.

\section{- ANALYTICAL PROCEDURE}

Our primary purpose in making these analyses was for comparison with soil and shale analyses. These comparisons will be more fully discussed elsewhere when more cores have been examined and especially when colloid data are available.

The cores from the sea bottom were prepared for analysis in accordance with the methods used by the United States Department of Agriculture in analyzing soils. ${ }^{2}$ More extensive descriptions of the fundamental methods have been given by Hillebrand and Lundell. ${ }^{10}$

The dried salts from sea water were not removed from the samples before analysis. If these had been removed by leaching, the results would have more closely simulated the actual composition of the sediments. However, such leaching, especially if extended, may remove some material that should properly be regarded as a part of the sediment. The results as obtained are a combination of the actual insoluble material and the amount of sea-water salts held by the sediment on drying. The amount of salts held by the sediments varies of course with the size of the particles and perhaps with the composition of the material.

The chlorine determinations represent the total chlorine in the sample. Analyses were made on 10 ignited saline samples to determine to what extent

8 Clarke, F. W., op. cit., pp. 543-593.

- Robinson, W. O., Method and procedure of soil analysis used in the Division of Soil Chemistry and Physics: U. S. Dept. Agr. Circ. 139, pp. 1-20, 1930.

10 Hillebrand, W. F., The analysis of silicate and carboñate rocks: U.S. Geol. Survey Bull. 700, pp. 1-285, 1919. Hil'ibrand, W. F., and Lundell, G. E. F., Applied inorganic analysis, with special reference to the analysis of metals, minerals, and rocks, pp. 645-849, New York, John Wiley and Suns, 1929. 
the chlorine was lost by ignition. The results are given in table 34 .

TABLE 34.-Chlorine content of dry sample and chlorine lost by ignition

\begin{tabular}{|c|c|c|}
\hline Sample number & $\begin{array}{c}\text { Chlorine } \\
\text { inoven-dry } \\
\text { sample } \\
\text { (percent) }\end{array}$ & $\begin{array}{c}\text { Chlorine } \\
\text { in ignited } \\
\text { sample } \\
\text { (percent) }\end{array}$ \\
\hline B22595_ & 1.55 & 0.11 \\
\hline B22596... & 1.84 & .26 \\
\hline C3938 & 1. 03 & 11 \\
\hline C3939 & 1. 03 & .09 \\
\hline C3940 & 1. 06 & .23 \\
\hline C3941 & 1. 26 & .25 \\
\hline C3942 & 1. 26 & 11 \\
\hline C 3943 & 1. 42 & .23 \\
\hline C3944 & 1.22 & 10 \\
\hline C3945_.... & 1. 11 & .24 \\
\hline
\end{tabular}

It is evident that not all the chlorine was volatilized by heating to a constant weight at about $900^{\circ} \mathrm{C}$. In determining the loss on ignition, some of the samples came to a constant weight by heating for 1 hour, whereas others required as much as 3 hours. Unfortunately, chlorine determinations were not made on all the samples analyzed.

The percentage of constituents is reported on the oven-dry basis. The inorganic constituents plus the ignition loss should equal very nearly 100 percent. The ignition loss includes constituents otherwise reported, such as nitrogen, carbon dioxide, organic matter, chlorine, and combined water.

\section{ANALYTICAL RESULTS}

All the analytical data obtained on the 31 samples examined are assembled in table 35 . They include, in addition to the normal analytical data obtained in a so-called complete soil analysis by the fusion method, organic matter, nitrogen, chlorine, hygroscopic water, and selenium. No attempt has been made to determine the quantities of minor elements probably present in the material. 
PART 9. SELENIUM CONTENT AND CHEMICAL ANALYSES

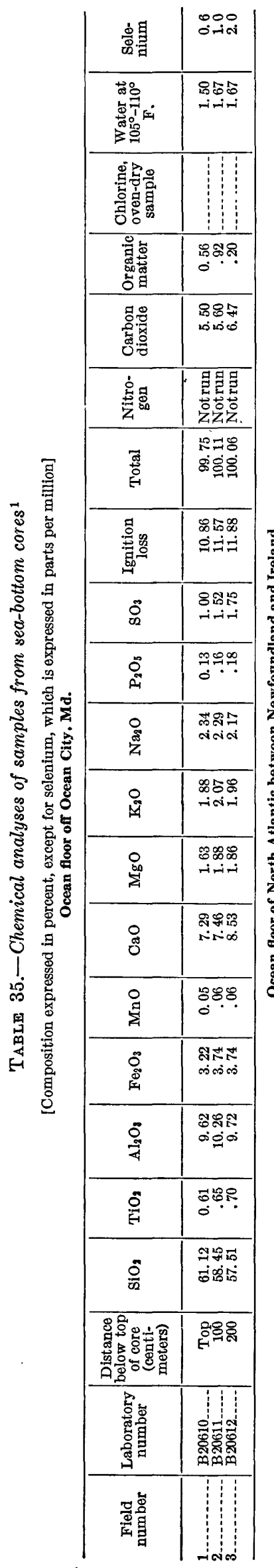

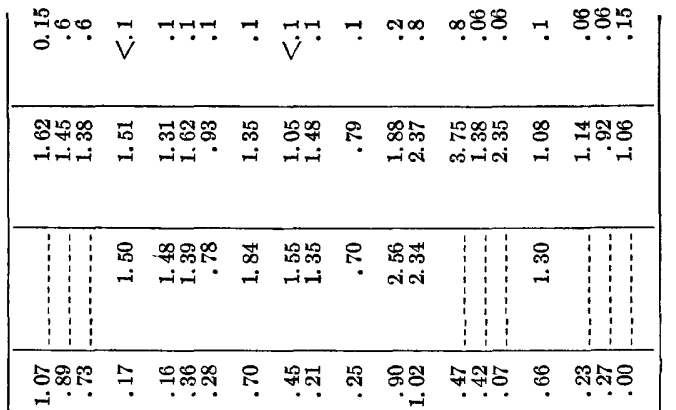

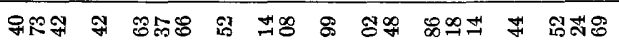

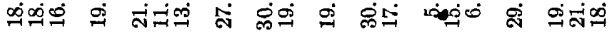

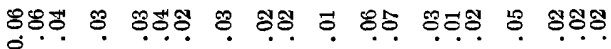

ఇ8ㅇำ ஜ्रां

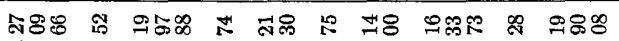

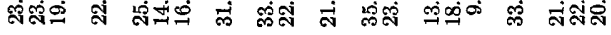

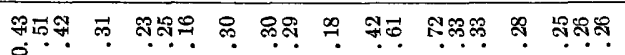

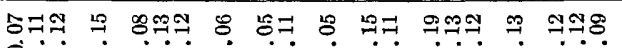

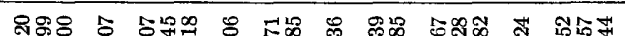

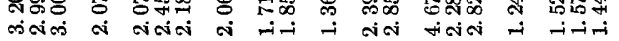
대유 म艹

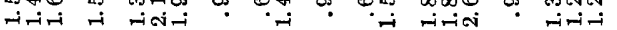

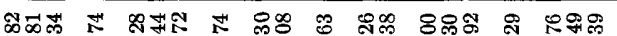

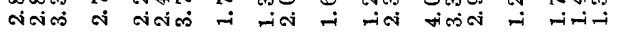

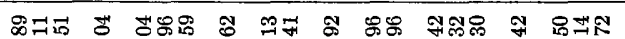

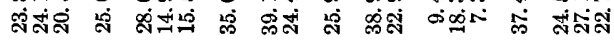

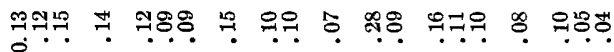

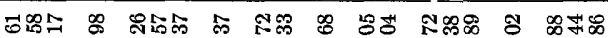

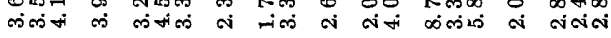

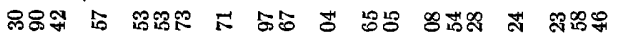

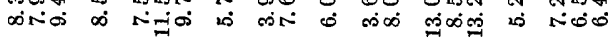

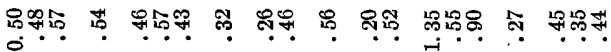

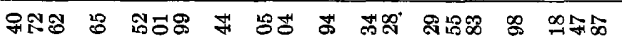

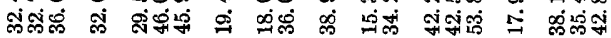

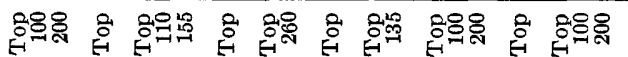

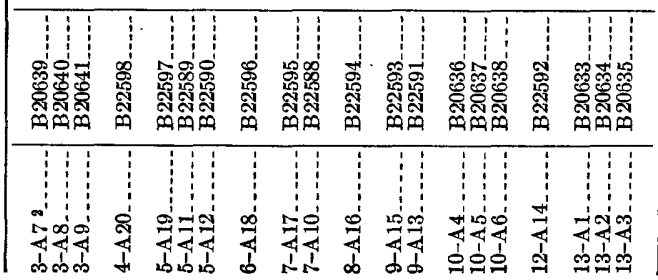

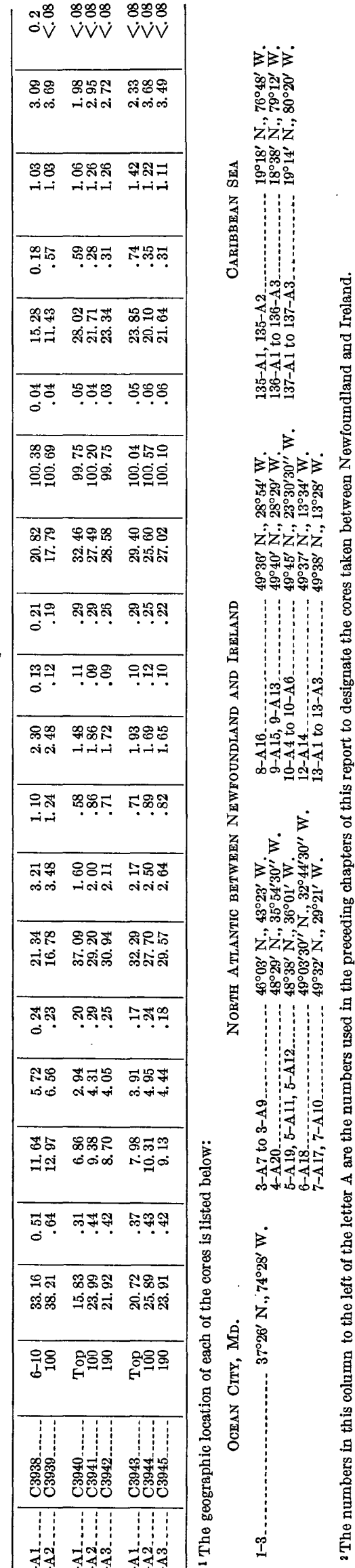




\section{INDEX}

Acknowledgments for aid

Page

Age of sediments

Analyses, chemical ......... $X, 151-155$ mechanical.

Archeology significance of core study for

Ash, volcanic, composition and distribution..................... vu

Barium, in sediments

Bartlett Deep, sediments from, analyses of

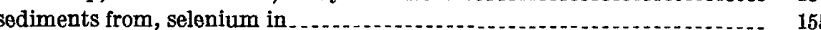

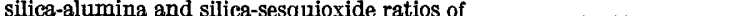

Basaltic glass, occurrence and character of . . . . .

Bering Sea, sediments from, selenium in .

oron, in sediments

Bottom currents, evidence of

Bradley, W. H., introduction by

Carbonate, in sediments ....................... vIII, 154

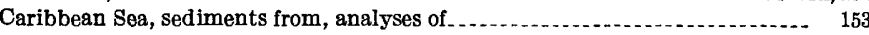

sediments from, silica-alumina and silica-sesquioxide ratios of . ......... 155

Carnegie Institution of Washington, work on deep-sea cores by ............. vII, XI, xIV

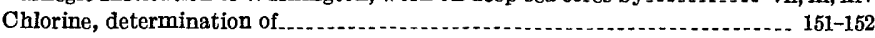

Clay, silica-alumina and silica-sesquioxide ratios of

Climate, relation of sediments to

Core samples, methods used in obtaining ......................... preparation of source of

Core stations, location of .................. XIv

Correlation of zones represented in the cores.

Crinoids, in sediments.

Currents, bottom, ovidence of

Diatomaceae

Diatoms, distribution of, in sediments. ............ VII-IX

Echinodermata

Echinoids, association of

Elphidiella .

Elphidium.

Farraday Hills, features of

Faunas, distribution of

Foraminifera, a and correlation of

VII-VII

Foraminiferal marl, meaning of term

Fossils, miscellaneous, distribution of

Gastropods, environment of.

-

features

Glass sbards, occurrence and character of

Globigerina ooze, meaning of term

Grain size of sediments
Introduction to complete report ........ Page

Lithologic zones in cores, correlation of

Lithology and geologic interpretations.

Location of region studied.

Mediterranean Sea, sediments in, significance of ............................. XIII-XIV

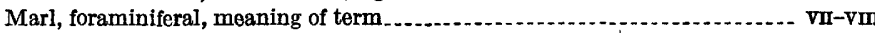

miranda, Pourtalesia.

Mississippi Delta, silt from, silica-alumina and silica-sesquiexide ratios of ....... 155

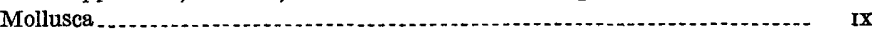

Mud-feeding organisms, role of

Ocean City, Md., sediments near, analyses of ................................... 153

sediments near, selenium in

silica-alumina and silica-sesquioxide ratios of ......................... 154

Ophiuroids, association of . . . .

Orgamic content of sediments................. IX

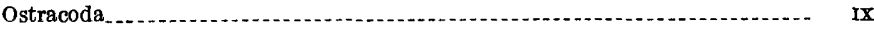

Outline of complete report

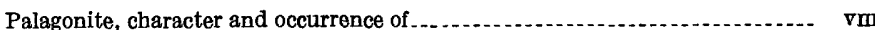

Pelecypods, en vironment of ........ IX

Piggot, C. S., coring device designed by........................

foreword by

Plankton, relation of, to organic content

Porosity of the sediments.

Pourtalesia miranda

Pteropod shells, distribution of .......... VIII, IX

Radium, concentration of, on ocean bottom....................................

Rare elements, spectroscopic tests for.......... VIII

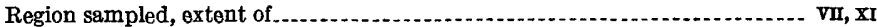

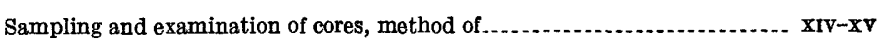

Sediments, age and correlation of

grain size of
organic content of

selenium in

silica-alumina and silica-sesquioxide ratios of . . . . . . . .

source of

Selenium content of sediments.

Silica-alumina and silica-sesquioxide ratios of sediments................ 154-155

Silt, silica-alumina and silica-sesquioxide ratios of $\ldots \ldots \ldots$

Spectroscopic tests of sediments.

Summary of complete report.................. VIII-x

Temperature, relation of type of sediment to................................ VII, $x$

Texture of sediments, relation of, to organic content........................ $\quad \mathbf{X}$

Uranium, in ocean sediments. ...................................................

Volcanic ash, composition and distribution of

Volcanic glass, occurrénce and character of

Zones represented in the cores, correlation of ............................... VII

XVII 

The use of the subjoined mailing label to return this report will be official business, and no postage stamps will be required

UNITED STATES DEPARTMENT OF THE INTERIOR GEOLOGICAL SURVEY

OFFICIAL BUSINESS This label can be used only for returning official publications. The address must not be changed. PENALTY FOR PRIVATE USE TO AVOID
PAYMENT OF POSTAGE, $\$ 300$ 
